\title{
Preparation and Quality Evaluation of Soymilk Carrot Blend
}

\author{
Ambreen Akhtar Saddozai ${ }^{1}$, Amer Mumtaz ${ }^{2}$, Naseem Rauf ${ }^{1}$, Saeeda Raza ${ }^{2}$, Nouman Rashid Siddiqui ${ }^{2}$, \\ Muhammad Naeem Safdar ${ }^{2}$, Sahar Shibli², Muhammad Suhail Ibrahim ${ }^{3 *}$, Muhammad Akhtar ${ }^{4}$ and \\ Muhammad Saad Rehan ${ }^{5}$
}

${ }^{1}$ Environmental Analytical Lab., NPSL, PCSIR, Islamabad, Pakistan; ${ }^{2}$ Food Sciences Research Institute, NARC, Islamabad, Pakistan; ${ }^{3}$ IFNS, PMAS ARID Agriculture University Rawalpindi, Pakistan; ${ }^{4}$ National Institute of Food Science and Technology, University of Agriculture, Faisalabad, Pakistan; ${ }^{5}$ Center for Advanced Studies in Energy (CAS-E), University of Engineering and Technology, Peshawar, Khyber Pakbtunkhwa, Pakistan.

\begin{abstract}
Shelf life of carrot supplemented soya milk was studied at two different temperatures to improve its pro vitamin A profile. Soymilk being potential source of protein was used as a carrier of pro- vitamin A. Carrot powder was blended in soya milk at three different concentrations levels $2 \%, 4 \%$ and $6 \%$ and packed in sterilized bottles. The product was kept at two different temperatures (ambient and refrigerated temperature) for 14 days to assess its shelf life. During the storage period the samples were analyzed for different chemical parameters total soluble solids, $\mathrm{pH}$, total carotenoids, protein contents and antimicrobial analysis. On the basis of quality attributes it was observed that plain and carrot supplemented soymilks remained acceptable up to 7 days at refrigerated temperature. Plain soymilk had lower TPC at both temperatures than carrot supplemented milk. pH, TSS, carotenoids and protein contents in samples were decreased with increased time at both the temperatures. Highest protein and carotenoid content was detected in $6 \%$ carrot supplemented milk.

Received | August 05, 2018; Accepted | January 04, 2021; Published | February 23, 2021

*Correspondence | Muhammad Suhail Ibrahim, IFNS, PMAS Arid Agriculture University Rawalpindi, Pakistan; Email: choudhary. mohammad@hotmail.com

Citation | Saddozai, A.A., A. Mumtaz, N. Rauf, S. Raza, N. Rashid, M.N. Safdar, S. Shibli, M.S. Ibrahim, M. Akhtar and M.S. Rehan. 2021. Preparation and quality evaluation of soymilk carrot blend. Pakistan Journal of Agricultural Research, 34(1): 85-90.

DOI | http://dx.doi.org/10.17582/journal.pjar/2021/34.1.85.90

Keywords | Soymilk, Evaluation, microbial quality, beta carotene, Carotenoid
\end{abstract}

\section{Introduction}

$\mathrm{C}$ arrots are equipped with phenolic contents and dietary fiber constituents got the attention of the processors and consumer as its modifies the end product functional prospertv (Viacava et al., 2019). Carrot powder has potential bioactive moieties hence effectively used in food fortification improve nutraceutical potential of end product without affecting its shelf life Alvarado-Ramírez et al. (2018). The basic cause of malnutrition (protein-energy malnutrition and micronutrient malnutrition) is poverty. Animal products and fruits are important sources of micronutrients yet are more expensive and unaffordable (Richard and Martins, 2008). Carrot powder is a good source of beta carotene and provitamin A (Madora et al., 2016). Soya milk blend with pineapple and carrot powder preserved its nutritional and microbial quality (Dauda et al., 2016). Functional carrot concentrate powder rich in carotenoid are currently used in various food industries to meet the consumer's demand for natural substitutes for food colorants (Haas et al., 2019). Soymilk is an aqueous, white, creamy extract produced from soybeans which resembles cow milk both in appearance and consistency. It is a highly nutritious 
food drink which contains protein, fat, carbohydrates, vitamins and minerals. It is because of this nutritious value and comparative low cost (Wilson, 1995), that soymilk plays an important role in the dietary need of people in most developing countries. Recently, the consumption of soymilk has greatly increased for reasons which include poverty alleviation and because it is recommended for people that cannot tolerate lactose since it does not contain lactose. It is continuously being used as a substitute to cow milk in most remote areas of Pakistan. This may also be because it has a few other known advantages over cow milk e.g. it has a beneficial effect in the prevention of protein energy malnutrition in infants and growing young children as well as in the prevention of osteoporosis and kidney diseases (Messina, 1995). Carrots are rich in carotenes, some compounds that the liver transforms to vitamin A. Carotenoids have been extensively studied due to their important biological functions for humans and also as a natural pigment. In 1919, relations between carotenoid and vitamin A were found, and in 1930 it was established that some of them have provitamin A activity (a-carotene, b-carotene, g-carotene, b-zeacarotene and others), which could be transformed in vitamin $A$ inside the animal organism (Roderguez, 1993). The main carotenoids in carrots are $\mathrm{a}-$ and $\mathrm{b}$-carotene, ranking from 80 to $90 \%$ of total carotenoids. The remaining consists of xanthophylls and non-corored polyenic pigments (3). According to Ramos (1991), main carotenoids in raw carrots of the Nantes variety were found b-carotene $(51,3 \%)$, a-carotene $(29,5 \%)$ and $\mathrm{d}$-carotene $(5,1 \%)$. In recent years, the consumption of carrot and its related products has increased steadily due to the recognition of antioxidant and anticancer activities of b- carotene in carrot which is also a precursor of vitamin A (Mridula, 2011). Carrots are processed into products such as dehydrated carrots, juice, beverages, candy and halwa.

The nutritious nature of soymilk however, makes it prone to microbial attack if not properly processed and stored as the nutrients it contains are also required for the growth of most spoilage organisms. A large number of microorganisms such as mesophilic aerobic bacteria, coliforms, yeasts and moulds are known to be responsible for the spoilage of soymilk, producing undesirable changes in the milk (Osuntongun and Aboaba, 2004). Fresh soymilk has a very short shelf life, which limits consumption to areas close to the production site. Thermal processing is the most common practice used to improve the microbial safety and extend the shelf life of soymilk because it inactivates vegetative pathogens and many spoilage bacteria. In some conditions, thermal processing, however, detrimentally affects nutritional and quality attributes of soymilk, and produces strong off flavor (Lozano et al., 2007). In Pakistan where protein malnutrition and vitamin A deficiency is prevalent in young children. This study was planned to prepare and evaluate nutritional quality and shelf life of vitamin-A supplemented soymilk at two different temperatures.

\section{Materials and Methods}

Soybean seeds were collected from Oilseed Research Program, NARC while carrots were purchased from the local market and processed at Food Sciences Research Institute, NARC.

\section{Production of carrot powder}

Fresh carrots were washed, scrapped and its end trimmed to remove dirt. It was grated using a grating machine and sun dried under cover until crispy. The dried carrots were grinded into powder with a blender at low speed and temperature. The powder thus produced was packaged in zippered polyethylene bags and stored at low temperature till use.

\section{Preparation of soy milk}

Soybeans were sorted and cleaned to remove dirt and stones; washed twice to remove dust and soaked for 18 hours. The soaked beans were grinded with water (1:5) ratio and sieved to get the soymilk. The soymilk was cooked for 23 minutes at $87^{\circ} \mathrm{C}$, refined sugar was added and the milk was allowed to cool (Enwere, 1998). Soymilk was then filled in washed, cleaned and pre-sterilized bottles having capacity of $100 \mathrm{ml}$.

\section{Supplementation of dried carrot}

Powdered carrot was supplemented in soymilk at three different ratios i.e. $2 \%, 4 \%$ and $6 \%$. At least 10 bottles of each treatment was prepared along with the control in $100 \mathrm{ml}$ bottle. Each soymilk bottle was air tightened with proper capping and kept at two different temperatures (refrigerated and ambient) for 14 days of storage.

\section{Microbial and chemical analysis}

Total Plate was determined according to described method (FAO, 1992). The protein content in fortified and unfortified samples was determined by using 
Kjeldahl's method as described in method of AOAC (2012). Nitrogen \% is multiplied $\mathrm{i}^{\text {th }}$ factor 6.25 to calculate the protein percentage. $\mathrm{pH}$ was determined by using Orion $\mathrm{pH}$ meter (Model $420 \mathrm{~A}+$ ). Total soluble solids content of a solution is determined by the index of refraction. This is measured using a refractometer and is referred to as the degrees Brix. Sugar concentration is expressed in degrees Brix. At $20^{\circ} \mathrm{C}$, The Brix is usually consider equivalent to the percentage of sucrose (sugar) in the solution $\cdot\left(60^{\circ}\right.$ Brix is equivalent to a sugar content of $60 \%)$. Total soluble solids (TSS) in these samples was determined with the help of $0-32^{\circ} \mathrm{B}$ Hand Refractometer (ATAGO, Japan).

\section{Carotenoid extraction}

Carotenoid extraction was based on the procedure described by Rodriguez et al. (1976). Samples (5 g) were ground with the help of chilled acetone and a micro grinder model TE 102, Tecnal and vacuum filtered using a Büchner funnel. This procedure was repeated until the residue became colorless and pigments were transferred to pet. ether, each fraction being washed with distilled water for complete acetone removal.

\section{Carotenoid analysis}

After extraction, the total carotenoid content of the pigments extracted was determined by spectrophotometer at $449 \mathrm{~nm}$, as proposed by Ramos (1991). A standard curve correlating total carotenoid concentration (expressed in $\beta$-carotene) and the absorbance of the pigment solution was used. An absorptivity coefficient of 2592 was used for $\beta$-carotene standard quantification (RodriguezAmaya, 1989).

\section{Statistical analysis}

Data obtained was analyzed by statistical package using Statistix 8.1 software. Complete randomized design was used for data analysis. Difference in mean values was compared by LSD test (Steel et al., 1997).

\section{Results and Discussion}

The results in Table 1 presents the total plate count of plain and carrot supplemented soymilk kept at room and refrigerated temperatures. It was observed that total plate counts (TPC) of soymilk increased with increase in storage period for samples stored at both temperature conditions. At 0 day TPC of fortified and plain soymilk of both temperature were 2.0x10 $2.9 \times 10^{1}, 3.0 \times 10^{1}$ and $5.9 \times 10^{0} \mathrm{CFU} / \mathrm{ml}$. After7 and 14 days TPC in fortified and plain soymilk samples stored at refrigeration condition increased from $4.2 \times 10^{3} \mathrm{CFU} / \mathrm{mL}$ to $2.0 \times 10^{4} \mathrm{CFU} / \mathrm{mL}$ while samples stored at room condition counts in fortified and plain samples increased from $5.9 \times 10^{4} \mathrm{CFU} / \mathrm{mL}$ to $1.0 \times 10^{6}$ $\mathrm{CFU} / \mathrm{ml}$, respectively. Similar findings were observed by Onuorah et al. (2007) in case of pasteurized soymilk samples. From the data it was observed that growth rate of TPC at refrigerated condition was less than as compared to room temperature. It means that freezing drastically reduced the microbial load on soymilk samples during storage. It was also find from the data that fortified milk of $6 \%$ ratio had the highest number of total plate counts both at room and refrigerated temperature followed by $4 \%$ and $2 \%$ while plain had least value of TPC at both temperature.

Gandhi (2009) had given the standards for soymilk and quoted the critical limit of SPC as 20,000 CFU/ $\mathrm{ml}$. Considering this standard critical limit of TPC, it was observed that all the fortified and plain soya milk samples were within safe limit up to seven days at refrigerated condition and unacceptable before seven days at room temperature, respectively. Further the microbial was increased drastically and beyond the standard limit, making the product unfit for consumption.

Increase in microbial load in soya milk might be due to its susceptibility as the availability of carbohydrates, proteins, and fat together with the neutral $\mathrm{pH}$ makes milk a perfect medium for microbial growth statistically the microbial count on soya milk sample showed significant difference with respect to increased number of storage days and change in treatment.

The results in Table 2 represents the total soluble solid content of plain milk and soya milk fortified with carrot powdered of different concentration. At 0 day value of TSS of samples varied from 5 to 5.6 at room temperature and 4 to 4.5 at refrigerated temperature while plain milk had 6.9 TSS. After seven and fourteen days plain milk showed highest content while among fortified soya milk of $6 \%$ concentration had the highest content both room as refrigerated storage condition and $2 \%$ showed lowest content of both temperature. From the data it was observed that rate of total soluble solid of plain and fortified soya milk samples decreased as the storage period increase. 
According to Fahmi et al. (2011) about half of the solids in the soya milk consist of soybean protein. As a common problem with soya milk is its lack of stability and sediment precipitation of proteins and other added solid particles such as minerals which might be the reason for lowered value of milk during storage.

The Table 3 represented the protein content of plain and fortified soy milk of different concentrations. Initial protein values of the fortified soymilk had ranged 3.15 to 3.30 and in plain soymilk it value was 3.1 both at room and refrigerated temperature. Protein content in samples decreased as the storage time increased. After 14 days of storage protein content in fortified soymilk had 2.67 to 2.51 while in plain milk protein values were 3.1 to 2.1 both at room as well as refrigerated temperature. Fortified soymilk with $6 \%$ had the highest value compared with the other samples while plain soymilk had least protein value. This result confirms published work that observed that when nutrient from different foods are blended the nutrients so produced would be better than any of the other food alone (Egbekun et al., 2004). As the protein content is affected by the state, temperature and $\mathrm{pH}$, the change in protein content might be due to change in concentration of above factors.

Table 1: Effect of Storage duration on total plate count of fortified and plain soymilk at refrigerated and room temperature (CFU/mL).

\begin{tabular}{|c|c|c|c|c|c|c|c|c|}
\hline \multirow{2}{*}{$\begin{array}{l}\text { Storage dura- } \\
\text { tion }\end{array}$} & \multicolumn{4}{|c|}{ Room temperature $\left(37^{\circ} \mathrm{C}\right)$} & \multicolumn{4}{|c|}{ Refrigerator temperature $\left(04^{\circ} \mathrm{C}\right)$} \\
\hline & $2 \%$ & $4 \%$ & $6 \%$ & Plain & $2 \%$ & $4 \%$ & $6 \%$ & plain \\
\hline 0 day & $2.0 \times 10^{1}$ & $2.9 \times 10^{1}$ & $3.0 \times 10^{1}$ & $5.9 \times 10^{0}$ & $2.0 \times 10^{1}$ & $2.9 \times 10^{1}$ & $3.0 \times 10^{1}$ & $5.9 \times 10^{0}$ \\
\hline 7 day & $5.9 \times 10^{4}$ & $6.9 \times 10^{4}$ & $8.0 \times 10^{3}$ & $2.4 \times 10^{4}$ & $4.2 \times 10^{3}$ & $6.9 \times 10^{3}$ & $9.0 \times 10^{3}$ & $1.0 \times 10^{3}$ \\
\hline 14 day & $6.0 \times 10^{6}$ & $7.9 \times 10^{6}$ & $9.3 \times 10^{6}$ & $1.0 \times 10^{6}$ & $1.0 \times 10^{5}$ & $2.9 \times 10^{5}$ & $3.7 \times 10^{5}$ & $2.0 \times 10^{4}$ \\
\hline
\end{tabular}

****The value are means of three replications.

Table 2: Effect of storage duration on Total Soluble Solid (TSS) offortified and plain soymilk at refrigerated and room temperature.

Storage dura-

tion

0 day

$2 \%$

7 day

14 day

\section{Room temperature $\left(37^{\circ} \mathrm{C}\right)$}

$4 \% \quad 6 \%$

$4.6 \pm 0.03$

$4.1 \pm 0.06$

$3.6 \pm 0.04$
$5.0 \pm 0.05$

$4.7 \pm 0.03$

$4.5 \pm 0.02$ plain

$6.9 \pm 0.07$

$6.2 \pm 0.06$

$5.6 \pm 0.05$
$2 \%$

$4.3 \pm 0.06$

$4.2 \pm 0.03$

$4.0 \pm 0.04$
Refrigerator temperature $\left(04^{\circ} \mathrm{C}\right)$

$4 \% \quad 6 \% \quad$ plain

$4.6 \pm 0.02 \quad 5.0 \pm 0.04 \quad 6.9 \pm 0.07$

$4.5 \pm 0.01 \quad 4.7 \pm 0.06 \quad 60.06 \pm 0.04$

$4.2 \pm 0.03 \quad 4.5 \pm 0.07 \quad 6.4 \pm 0.03$

**** The value are means of three replications.

Table 3: Effect of storage duration on protein content of fortified and plain soymilk at refrigerated and room temperature.

\section{Storage}

duration

0 day

7 day

14 day
Room temperature $\left(37^{\circ} \mathrm{C}\right)$

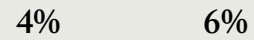

$3.20 \pm 0.06$

$3.30 \pm 0.04$

$2.71 \pm 0.04$

$2.59 \pm 0.03$

$2.90 \pm 0.06$

$2.65 \pm 0.06$ plain $\quad 2 \%$

$3.1 \pm 0.02$

$2.6 \pm 0.04$

$2.1 \pm 0.06$
Refrigerator temperature $\left(04^{0} \mathrm{C}\right)$

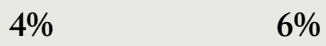

plain

$3.15 \pm 0.02$

$3.20 \pm 0.02$

$3.30 \pm 0.02$

$3.1 \pm 0.02$

$3.12 \pm 0.04$

$30.01 .18 \pm 0.02$

$3.27 \pm 0.03$

$3.08 \pm 0.04$

$3.10 \pm 0.05$

$3.17 \pm 0.01$

$3.25 \pm 0.04$

$3.06 \pm 0.04$

Table 4: Effect of storage duration on pH of fortified and plain soymilk at refrigerated and room temperature.

\section{Storage \\ duration}

0 day

7 day

14 day

\section{Room temperature $\left(37^{\circ} \mathrm{C}\right)$}

$4 \% \quad 6 \%$

$4.6 \pm 0.02$

$4.1 \pm 0.03$

$3.6 \pm 0.06$
$5.0 \pm 0.05$

$4.7 \pm 0.04$

$4.5 \pm 0.02$ plain

$6.9 \pm 0.0 .07$

$6.2 \pm 0.07$

$5.6 \pm 0.08$

\section{Refrigerator temperature $\left(04^{\circ} \mathrm{C}\right)$}

$\begin{array}{lll}4 \% & 6 \% & \text { plain } \\ 4.6 \pm 0.06 & 5.0 \pm 0.02 & 6.9 \pm 0.07 \\ 4.5 \pm 0.05 & 4.7 \pm 0.03 & 6.6 \pm 0.06 \\ 4.2 \pm 0.02 & 4.5 \pm 0.06 & 6.4 \pm 0.08\end{array}$

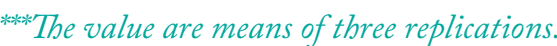


Table 5: Effect of storage duration on the beta-carotene content $(\mathrm{ug} / \mathrm{g})$ of fortified and plain soymilk at refrigerated and room temperature.

\begin{tabular}{lllllllll} 
Storage dura- & \multicolumn{4}{c}{ Room temperature } & \multicolumn{4}{c}{ Refrigerator temperature } \\
tion & $\mathbf{2 \%}$ & $\mathbf{4 \%}$ & $\mathbf{6 \%}$ & Control & $\mathbf{2 \%}$ & $\mathbf{4 \%}$ & $\mathbf{6 \%}$ & Control \\
0 day & $899 \pm 09$ & $986 \pm 10$ & $1054 \pm 13$ & Traces & $899 \pm 07$ & $986 \pm 11$ & $1054 \pm 13$ & Traces \\
7 day & $786 \pm 10$ & $976 \pm 12$ & $1036 \pm 07$ & Nil & $865+08$ & $967 \pm 10$ & $1042 \pm 12$ & Nil \\
14 day & N.D & N.D & N.D & N.D & $854+08$ & $934 \pm 10$ & $995 \pm 10$ & Nil
\end{tabular}

**athe value are means of three replications.

Table 4 indicated the results of $\mathrm{pH}$ of $2 \%$ carrot powder soymilk blend stored at room temperature reduced the $\mathrm{pH}$ from 4.3 to 3.4 . $4 \%$ blend reduced the $\mathrm{pH}$ from 4.6 to $3.6,65$ reduced $\mathrm{pH}$ from 6.5 to 5.4 and plain reduced $\mathrm{pH}$ from 6.9 to 5.6 , respectively. $2 \%$ blended soya milk stored at refrigerator temperature reduced $\mathrm{pH}$ from 4.3 to $4.00,4 \%$ reduced the $\mathrm{pH}$ from 4.6 to $4.2,65$ reduced the $\mathrm{pH}$ from 5.00 to 4.5 and plain reduced its $\mathrm{pH}$ from 6.9 to 6.4 , respectively.

Table 5 represents the beta-carotene content of plain and carrot supplemented milk kept at room and refrigerated temperatures. Carotene content was decrease with the passage of storage period at both the temperatures. At room temperature beta-carotene was decreased $12.56 \%$ in $2 \%$ carrot supplemented soymilk, $11.16 \%$ in $4 \%$ carrot supplemented soymilk and $1.71 \%$ in $6 \%$ carrot supplemented soymilk. At refrigerated temperature the decline in carotene was observed 5\%, 5.3 \% and 5.6\% in 2,4, $6 \%$ carrot supplemented soymilk, respectively.

\section{Novelty Statement}

Pro-vitamin containing nutritious soymilk was prepared, standardized and studied for shelf life.

\section{Author's Contribution}

Ambreen Akhtar Saddozai: Conceived the idea.

Amer Mumtaz: Prepared Main draft of the research paper.

Naseem Rauf: Prepared references.

Saeeda Raza: Arranged tables.

Nouman Rashid: Abstract write up and finalized draft.

Naeem Safdar: Proof reading of the final draft.

Sahar Shibli: Participated in microbiological study.

Muhammad Suhail Ibrahim: Compilation of the data for analysis.

Muhammad Akhtar: Data analysis using statistical techniques.

Muhammad Saad Rehan: Input given in introduction write up.

Conflict of interest

The authors have declared no conflict of interest.

\section{References}

Alvarado-Ramírez, M., J. Santana-Gálvez, A. Santacruz, L.D. Carranza-Montealvo, E. Ortega-Hernández, J. Tirado-Escobosa and D.A. Jacobo-Velázquez. 2018. Using a functional carrot powder ingredient to produce sausages with high levels of nutraceuticals. J. Food Sci., 83(9): 2351-2361. https://doi. org/10.1111/1750-3841.14319

AOAC, 2012. Official methods of analysis, $17^{\text {th }} \mathrm{Ed}$. Association of Official Analytical Chemists, Virginia, USA.

Carvalho, P.R.N., 1993. Análise de vitaminas em alimentos. ITAL, Não paginado, Campinas.

Dauda, A.O., A.O. Abiodun and U.I. Ibanga. 2016. Stability of blend of carrot, pineapple and soymilk treated with Aframomum danielli powder. Agrosearch, 16(2): 1-6. https://doi. org/10.4314/agrosh.v16i2.1

Egbekun, M.K., P.C. Isolokeu and P.I. Akubor. 2004. Chemical and sensory properties corn cassavasoybeanflour blends for the production of "Ojeaku"-A Nigeria traditional food. Book of abstracts, Nutr. Soc. Nigeria, pp. 9-15.

Enwere, N.J., 1998. Foods of plant origin. Afro Orbis Publications Ltd., pp. 22-27, 219-221.

Fahmi, R., F. Khodaiyan, R. Pourahmad and Z.E. Djomeh. 2011. Effect of ultrasound assisted extraction upon the protein content and rheological properties of the resultant soymilk. Adv. J. Food Sci. Technol., 3(4): 245-249.

FAO, 1992. Manual of food quality control, review, microbiological analysis $\mathrm{FAO}$ and nutrition 
paper. Food and Agriculture Organization of United Nation, Rome.

Gandhi, A.P., 2009. Review article on quality of soybean and its food products. Int. Food Res. J., 16: 11-19.

Haas, K., P. Robben, A. Kiesslich, M. Volkert and H. Jaeger. 2019. Stabilization of crystalline carotenoids in carrot concentrate powders: Effects of drying technology, carrier material, and antioxidants. Foods, 8(8): 285. https://doi. org/10.3390/foods8080285

Lozano, P.R., M. Drake, D. Benitez and K.R. Cadwallader. 2007. Instrumental and sensory characterizations of heat-induced odorants in aseptically packaged soymilk. J. Agric. Food Chem., 55(8): 3018-3026. https://doi. org/10.1021/jf0631225

Madora, E.P., T.K. Takalani and M.E. Mashau. 2016. Physicochemical, microbiological and sensory properties of low fat yoghurt fortified with carrot powder. Int.J.Agric. Biol.Eng., 9(1): 118-124.

Messina, T.M., 1995. Soy products as common alternatives to cow milk products. Ann. Microbiol., 50: 43-53.

Mridula, D., 2011. Physico-chemical and sensory characteristics of $\$$ - carotene rich defatted soy fortified biscuits. Afr. J. Fd. Sci., 5: 305-312.

Onuorah, C.E., A.O. Adejare and N.S. Uhiara. 2007. Comparative physio-chemical evaluation of soymilk and soya cake produced by three different methods. Niger. Food J., 25(2): 28-38. https://doi.org/10.4314/nifoj.v25i2.50838

Osuntogun, B. and O.O. Aboaba, 2004. Microbiological and physico chemical evaluation of some Nonalcoholic beverages. Pak. J. Nutr., 3: 188192. https://doi.org/10.3923/pjn.2004.188.192 Quackenbush, F.W. and R.L. Smallidge. 1986. Nonaqueous reverse phase liquid chromatographic system for separation and quantification of provitamin A. J. Assoc. Off. Anal. Chem., 69(5): 767-777. https://doi. org/10.1093/jaoac/69.5.767
Ramos, D.M.R., 1991. Avaliação das perdas de carotenóides evalor de vitamina $\mathrm{A}$ durante a desidratação ea liofilização industrial de cenoura e espinafre. (Tese M.S.), Universidade Estadual de Campinas, Campinas, pp. 106.

Richard, D.S. and W.B. Martin. 2008. Nutrition and health in developing countries. Humana Press, pp. 497-499.

Rodriguez, D.B., L.C. Raymond, T. Lee, K.L. Simpson and C.O.Chichester.1976. Carotenoid pigment changes in ripening Momordica charantia fruits. Ann. Bot., 40: 615-624. https:// doi.org/10.1093/oxfordjournals.aob.a085171

Rodriguez-amaya, D.B., 1993a. Nature and distribution of carotenoids in foods. In: Shelf life studies of foods and beverages chemical, biological, physical and nutritional aspects, Charalambous, F. (ed), Elsevier Science, Amsterdam, pp. 547-589.

Rodriguez-amaya, D.B. 1993b. Stability of carotenoids during the storage of foods In Shelf life studies of foods and beverages-chemical, biological, physical and nutritional aspects, Charalambous, F. (ed). Elsevier Science, Amsterdam, p. 591-596.

Rodriguez-amaya, D.B., 1989. Critical review of provitamin A determination in plant foods. J. Micronutr. Anal., 5: 191-225.

Steel, R.G.D., J.H. Torrie and D.A. Dickey. 1997. Principles and procedures of statistics: A biometrical approach. $3^{\text {rd }}$ Edn., McGraw-Hill, Singapore.

Viacava, F., J. Santana-Gálvez, E. Heredia-Olea, E. Pérez-Carrillo and D.A. Jacobo-Velázquez. 2019. Combined application of wounding stress and extrusion as an innovative tool to obtain carrot powders with modified functional properties. CyTA J. Food, 17(1): 613-621. https://doi.org/10.1080/19476337.2019.1624 621

Wilson, L., 1995. Soyfoods. In: Erickson, D.L. (Ed.), practical handbook of soybean processing and utilization. AOCS Press, Chalingo. 